\title{
The Relationship Between Gamification, Brand Engagement and Brand Equity
}

\author{
Nannan Xi \\ Gamification Group \\ University of Turku \\ nannan.xi@tut.fi
}

\author{
Juho Hamari \\ Gamification Group \\ Tampere University \\ juho.hamari@tut.fi
}

\begin{abstract}
Many companies are increasingly attempting to build and manage brand communities that increasingly resemble games and game communities and believe that this gamification can increase the engagement and loyalty of consumers to the brand. However, currently, there is a dearth of empirical evidence supporting these expectations in the realm of marketing beyond the pervasive hype around gamification. Therefore, in this study, we investigate the relationship between gamification features, brand engagement and brand equity among consumers $(N=824)$ from both of Xiaomi and Huawei online brand communities through a psychometric survey. The results indicate that achievement and social-related features are positively associated with emotional, cognitive and social brand engagement. Immersion-related features are positively associated with social brand engagement. Furthermore, all dimensions of brand engagement are further positively associated with brand equity. The results imply that there is a positive chain relationship between gamification, brand engagement and brand equity, and that, gamification appears to be an effective tool for brand management.
\end{abstract}

\section{Introduction}

Gamification refers to the design that attempts to bring about similar positive experiences as games do, and consequently, affect user behaviour and cognitive processes [27]. In the marketing realm, gamification has been used by many enterprises to improve advertising performance $[50,56]$, engage customers [21, 45] and enhance perceived brand value [55]. Especially in brand management, many international companies adopt gamification techniques to increase consumers' brand awareness, brand attitude and brand loyalty, such as Where's Waldo on Google Map, Ant forest of Alipay and Samsung Nation online community, etc. Although gamification has offered a novel way for marketers $[16,17,23,27,36,50,55]$, the mechanisms of how gamification may impact brand success remains unclear due to lack of empirical evidence within this field.

Relevant research that has examined the relationship between gamification and brand equity is still at an initial stage, mainly focused on brand attitude $[50,55]$, brand engagement $[4,21]$ and brand involvement [41], lack of in-depth discussion. Brand equity, as one of the important goals of social media marketing, only received limited attention in the gamification-related literature.

Therefore, the objective of the present paper is to investigate the relationship between customers' interaction with different gamification features and emotional, cognitive and social brand engagement and further brand equity in social commerce. We employ an online survey conducted among consumers $(\mathrm{N}=824)$ from gamified brand communities of Xiaomi and Huawei, which are two of the successful gamified services in China.

\section{Background}

\subsection{Gamification}

2.1.1. Gamification. Gamification refers to the design that attempts to bring about similar positive experiences as games do, and consequently affect user behaviour and cognitive processes [27]. As the main inspiration of gamification is games, gamification commonly employs game mechanics. For instance, in the business context, different gamification features can be integrated into service, product, advertisement website, etc, in order to increase participation [45], engagement [21, 23, 43] and loyalty [61]. In the body of literature related to game and gamification studies, it is most established to make a distinction between three primary categories of game/gamification mechanics and game-design related gaming motivations: immersion-related, achievement-related and social- 
related dimensions [19, 36, 42, 47, 57, 58]. Immersionrelated features primarily attempt to immerse the player in self-directed inquisitive activity, and include such game mechanics as avatars, storytelling, narrative structures, role-play mechanics, etc. Achievementrelated features primarily attempt to increase players' sense of accomplishment and include such game mechanics as badges, challenges, missions, goals, leaderboards, progression metrics, etc. Social-related features primarily attempt to enable players social interaction, and include such game mechanics as cooperation/collaboration structures, praise, etc.

2.1.2. Gamification and brand management. Given that gamification in marketing is still a new area, only a few studies have empirically investigated the relationship between gamification and aspects of brand management. The literature has thus far focused on the relationship between gamification/game and brand attitude [50, 55], brand recall [38], brand engagement [4], brand involvement [41], brand equity [26], service use [16], continued use [18] and purchase intentions [30]. Overall, the current body of literature suggests that gamification may have a positive effect on brand equity.

However, across this body of research, the biggest glaring problem is that most studies did not measure the users' interaction with gamification but rather assume that users would have been exposed to gamification, and therefore, on a vaguer level often retort to investigating the intentions of people to e.g. continue using the gamified system. Another limitation of the current body of literature is that most studies only investigated the association between only few gamification mechanics and brand-related aspects, essentially only covering a small portion of the research question related to gamification and consumer behaviour. Moreover, the relationship between gamification and brand management is not usually clearly theoretically specified in past research [36].

\subsection{Brand Engagement}

Band engagement is considered to be co-creative customer experiences where consumers interact with a focal agent/object (e.g. a brand), which then further reflects the nature of consumers' particular interactive brand relationships $[5,14,25,49]$. Generally speaking, brand engagement can be seen as a multidimensional psychological state that is a consequence of interacting with a brand. It includes aspects of emotional, cognitive and social engagement [6, 51, 52, 60]. Emotional aspect of brand engagement is related to affection refers to "a consumer's degree of positive brand-related affect in a particular consumer/brand interaction" [25] or enthusiasm refers to "the zealous reactions and feelings of a person related to using or interacting with the focus of their engagement" [48, 52]. Unlikely, cognitive engagement, which is the extent of individuals' cognitive investment in specific brand interactions [24]. Cognitive brand engagement refers to the degree of interest the person has or wishes to have in interacting with the focus of their engagement, named conscious attention [52], the duration of focus on [48] or the brand-related thought processing and elaboration in brand interaction [25]. Social brand engagement [51, 52, 60], involves enhancement of the interaction based on the inclusion of others with the focus of engagement.

A few gamification-related studies have explored the relationship between gamification and brand engagement. However, existing evidence of their relationship is still wanting. For example, based on flow theory, Berger et al. [4] showed that gamified interactions, which are highly interactive and optimally challenging, are positively related to emotional and cognitive dimensions of brand engagement. Gatautis et al. [15] conducted the empirical study on the impact of gamification on consumer brand engagement in the Lithuanian market. Even though the relationship was not strong according to the empirical result, there are reasons to believe that gamification can positively affect brand engagement.

Regarding the relationship between gamification and brand engagement, currently, there does not exist clear empirical basis on which to sturdy base hypotheses on. However, if we draw from larger game and gamification research $[19,36,42,47,57,58]$ and brand engagement literature [31, 35], parallels between classes of gamification features and dimensions of brand engagement can be drawn. Immersive features are commonly connected to more emotional and affective aspects of experience and engagement: being immersed in stories, narrative, and feelings (e.g. Yee, [57]). Thus, when customers interact with immersionrelated features such as storytelling, narrative structures, role-play mechanics, etc., customers can be predicted to be more likely to have positive feelings, passions and express more enthusiasm towards the specific brand. Whereas achievement-oriented features and play is commonly tied to more cognitive style, goal-driven engagement and behaviour (e.g. Yee, [57]). Achievement-related features are composed of goalstructures and optimizing one's behaviour etc. that require more cognitive processes, therefore it can be assumed that achievement-related features are more likely to be associated most strongly with cognitive brand engagement. Social related game features can be assumed to be naturally linked with social engagement. 
When there are more social-oriented features in online brand-related context, customers can easily get/share information about the brand from/to others. The customer may become a brand propagandist, strengthening the connection with others based on specific brand [22]. Thus, we put forward the following hypotheses:

H1. Interaction with immersion-related gamification features is positively and more strongly associated with emotional brand engagement than with other dimensions of brand engagement.

H2. Interaction with achievement-related gamification features is positively and more strongly associated with cognitive brand engagement than with other dimensions of brand engagement.

H3. Interaction with social-related gamification features is positively and more strongly associated with social brand engagement than with other dimensions of brand engagement.

\subsection{Brand equity}

Brand equity can be regarded as one of the most core parts of intangible assets a company has [34, 46], and which can bring competitive advantages [37]. In this study, we focus on brand equity from the perspective of the individual consumer (customerbased brand equity), which originates from traditional cognitive psychology and information economics. Customer-based brand equity refers to the differential effect of brand knowledge on customer response to the marketing of brand [32], or the different response between a focal brand and an unbranded product [59]. Brand equity is commonly defined through the consumer awareness of brand and their loyalty to the brand [1].

Brand engagement is often considered one part of corporate societal marketing to build brand equity [22]. When customers are willing to invest more time, energy and money, they might be more loyal to a brand. Also, customers who have higher engagement with a brand can be more satisfied with the brand and higher loyalty [54]. In addition, when customers actively interact with a brand in social media-based context, not only they will review some information about the brand, but also recommend this brand to others and has higher intentions to buy [28]. We can easily expect that brand engagement is positively related to brand equity.

Consistent with the brand-related literature, in this study, we expect that the three different dimensions of brand engagement will facilitate brand equity. When customers have a positive emotion with the brand, the strong feelings can drive consumers' strong desire to keep a positive relationship with brand, which can lead to repeat purchasing behaviour or the willingness of continue to use, which further increase the brand loyalty. Moreover, when customers positively engage with the brand, they will often pay more attentions to the relevant information of the enterprise or brand per se, discuss and share the brand with other customers, which bring higher brand awareness. Therefore, the following hypothesis can be proposed:

H4. Brand engagement (emotional, cognitive and social) is positively associated with brand equity.

\section{Empirical study}

\subsection{Measurement}

We conducted an online survey lasting almost three months in Xiaomi and Huawei gamified online brand communities, which represents two large technology product-related online brand communities in China. Based on the T-test results of the samples from the first month and the last month respectively, there is no significant difference between different samples. Three master students extracted the gamification features in both of the two online brand communities separately, and two $\mathrm{PhD}$ candidates integrated those similar elements. A total of thirteen gamification features were identified. Surprisingly, both communities employed the same set of gamification features even though their implementation varied between the communities. Based on the research from Yee [57] and Koivisto \& Hamari [36], in this study, avatars/virtual identity/profile, customization/personalization features and narrative/story are categorized as immersionrelated features; badges/medals/trophies, virtual currency/coins, points/score/experience points, status bar/progress, level, leaderboards/rankings/highscore lists and increasingly difficult tasks are achievementrelated features; competition, cooperation and social network features are social-related features. The participants were asked to estimate the frequency at which they interact with each feature and the importance of that interaction. We measured all of the items using then 7-point scale, ranging from 1 (no at all important) to 7 (extremely important) and from 1 (never) to 7 (every time). In accordance with prior research on games and gamification, the mechanics were divided into three latent constructs: interaction with immersion-related gamification features (3), achievement-related gamification features (7) and social-related gamification features (3).

Further, we assessed emotional brand engagement with five items, cognitive brand engagement with four items and social brand engagement with six items based on So et al. [48], Vivek [51] and Vivek et al. 
[52]. A 7-point scale was provided, ranging from 1 (strongly disagree) to 7 (strongly agree). Higher scores indicated higher consumer brand engagement in the emotional, cognitive and social dimension.

Measurement of brand equity included brand awareness and brand loyalty. Four items to measure brand loyalty were adapted from Chaudhuri \& Holbrook [8], Washburn \& Plank [53] and Yoo \& Donthu [59]; five items to measure brand awareness were adopted from Washburn \& Plank [53] and Yoo \& Donthu [59]. All of those items were slightly modified to fit the context of the study.

\subsection{Participants}

A sample of 824 respondents (464 from the Xiaomi community and 360 from Huawei community, respectively) participated in the study over a threemonth period.

Table 1. Demographic information

\begin{tabular}{|c|c|c|}
\hline & $\mathbf{N}$ & $\%$ \\
\hline \multicolumn{3}{|l|}{ Gender } \\
\hline Male & 427 & $51.8 \%$ \\
\hline Female & 397 & $48.2 \%$ \\
\hline \multicolumn{3}{|l|}{ Age } \\
\hline-19 & 16 & $1.9 \%$ \\
\hline $20-29$ & 338 & $41.0 \%$ \\
\hline $30-39$ & 321 & $39.0 \%$ \\
\hline $40-$ & 149 & $18.1 \%$ \\
\hline \multicolumn{3}{|l|}{ Occupation } \\
\hline A student & 166 & $20.1 \%$ \\
\hline Self-employed & 45 & $5.5 \%$ \\
\hline Employed for wages & 410 & $49.8 \%$ \\
\hline Military/Government & 77 & $9.3 \%$ \\
\hline professional/technical & 94 & $11.4 \%$ \\
\hline Unemployed & 18 & $2.2 \%$ \\
\hline Others & 14 & $1.70 \%$ \\
\hline \multicolumn{3}{|l|}{ Education } \\
\hline Middle school & 8 & $1.0 \%$ \\
\hline $\begin{array}{l}\text { High school/ Vocational } \\
\text { education/technical school }\end{array}$ & 41 & $5.0 \%$ \\
\hline Associate's degree & 66 & $8.0 \%$ \\
\hline Bachelor's degree & 539 & $65.4 \%$ \\
\hline Master's degree and above & 170 & $20.6 \%$ \\
\hline \multicolumn{3}{|l|}{ Income per month (rmb) } \\
\hline-2499 & 25 & $3.0 \%$ \\
\hline $2500-4999$ & 200 & $24.3 \%$ \\
\hline $5000-7499$ & 167 & $20.3 \%$ \\
\hline 7500-9999 & 223 & $27.1 \%$ \\
\hline $10000-12499$ & 116 & $14.1 \%$ \\
\hline $12500-14999$ & 53 & $6.4 \%$ \\
\hline $15000-17499$ & 27 & $3.3 \%$ \\
\hline 17500-19999 & 6 & $0.7 \%$ \\
\hline 20000- & 7 & $0.8 \%$ \\
\hline
\end{tabular}

Table 1 presents the demographic characteristics of the respondents. The gender distribution of the sample is equal with male respondents representing $51.8 \%$ and female respondents representing 48.2\%. Regarding age, most of the respondents were between the ages of 20 and 39, taking up $80 \%$. Most respondents completed a bachelor's degree (86\%); $49.8 \%$ are employed for wages and $20.15 \%$ are students. $97 \%$ respondents' monthly income is higher than $2499 \mathrm{RMB}$ and $0.8 \%$ is over 19999 RMB.

\subsection{Measure model}

The analysis of validity and reliability of the measurement model as well as the analysis of the path model was undertaken using the component-based PLS-SEM (Smart-PLS 3.0). When the measurement model includes formative constructs, PLS-SEM is considered more appropriate structural equation modelling technique when compared to CB-SEM [2, 9, 10, 20, 39]. According to the understanding of formative construct from Jarvis et al. [29] and Rossiter [44], in this study, three different gamified interactions are formative constructs, since frequency and importance of each gamification feature is posited as the common cause of construct and variation in item measures causes variation in the construct. Contrariwise, three dimensions of brand engagement and brand equity are reflective models given that indicators are assumed to be caused by the latent variable. The model includes both formative constructs (interactions with gamification features) and reflective constructs (brand engagement and brand equity).

3.3.1. Formative measurement model. The validity of formative constructs is assessed differently from reflective measurement. With formative constructs, the assumption is not that items would correlate but rather the construct is "formed" from the indicators. We assessed collinearity and external validity of formative measurement model. The variance inflation factors (VIF) for each indicator indicate the possible presence of collinearity. For formative measures, VIF values greater than 3.3 indicate high multicollinearity [12]. After running the PLS algorithm, all VIFs range from 2.457 to 1.539 (lower than 3), which suggest that multicollinearity is not a threat. Some authors suggest testing the external validity of a formatively measured construct instead of internal consistency examinations (e.g., Cronbach's alpha, [3, 11]), thus this study assessed the validity of formative constructs by evaluating indicator weights and loadings. Indicators of well-specified formative constructs should have statistically significant weights [7], but indicators with 
statistically non-significant weights but high loadings have high absolute (though low relative) influence on the construct and should be retained in the model [40]. Even though some indicators do have low weights and non-significant, all indicators have high loadings (above 0.565), which indicates acceptable external validity. Table 2 presents the loading, weight and VIF of formative measurement.

Table 2. Formative measurement

\begin{tabular}{|c|c|c|c|c|}
\hline \multicolumn{2}{|c|}{ Construct } & Loading & Weight & VIF \\
\hline \multicolumn{5}{|c|}{ Interaction with immersion-related features } \\
\hline \multicolumn{5}{|c|}{-The importance of interacting with } \\
\hline IIF1 & $\begin{array}{l}\text { avatars/virtual } \\
\text { identity/profile }\end{array}$ & 0.691 & 0.003 & 2.068 \\
\hline IIF2 & $\begin{array}{l}\text { customization/ } \\
\text { personalization }\end{array}$ & 0.729 & 0.283 & 1.539 \\
\hline IIF3 & narrative/story & 0.771 & 0.264 & 1.847 \\
\hline \multicolumn{5}{|c|}{-The frequency of interacting with } \\
\hline FIF1 & $\begin{array}{l}\text { avatars/virtual } \\
\text { identity/profile }\end{array}$ & 0.889 & 0.508 & 1.936 \\
\hline FIF2 & $\begin{array}{l}\text { customization/ } \\
\text { personalization }\end{array}$ & 0.699 & 0.149 & 1.667 \\
\hline FIF3 & narrative/story & 0.703 & 0.047 & 2.031 \\
\hline \multicolumn{5}{|c|}{ Interaction with achievement-related features } \\
\hline \multicolumn{5}{|c|}{-The importance of interacting with } \\
\hline IAF1 & $\begin{array}{l}\text { badges/medals/ } \\
\text { trophies }\end{array}$ & 0.739 & 0.124 & 2.085 \\
\hline IAF2 & $\begin{array}{l}\text { virtual } \\
\text { currency/coins }\end{array}$ & 0.682 & 0.047 & 2.046 \\
\hline IAF3 & $\begin{array}{l}\text { points/scores/ } \\
\text { experience } \\
\text { points }\end{array}$ & 0.674 & 0.077 & 1.994 \\
\hline IAF4 & $\begin{array}{l}\text { status bars/ } \\
\text { progress bars }\end{array}$ & 0.614 & -0.032 & 1.857 \\
\hline IAF5 & $\begin{array}{l}\text { avatars/ } \\
\text { virtual identity/ } \\
\text { profile levels }\end{array}$ & 0.810 & 0.271 & 2.205 \\
\hline IAF6 & $\begin{array}{l}\text { leaderboards/ } \\
\text { rankings/ } \\
\text { highscore lists }\end{array}$ & 0.602 & -0.064 & 1.870 \\
\hline IAF7 & $\begin{array}{l}\text { increasingly } \\
\text { difficult tasks }\end{array}$ & 0.685 & 0.027 & 2.033 \\
\hline \multicolumn{5}{|c|}{-The frequency of interacting with } \\
\hline FAF1 & $\begin{array}{l}\text { badges/medals/ } \\
\text { trophies }\end{array}$ & 0.791 & 0.229 & 2.290 \\
\hline FAF2 & $\begin{array}{l}\text { virtual } \\
\text { currency/coins }\end{array}$ & 0.615 & 0.108 & 1.582 \\
\hline FAF3 & $\begin{array}{l}\text { points/scores/ } \\
\text { experience } \\
\text { points }\end{array}$ & 0.730 & 0.063 & 2.322 \\
\hline FAF4 & $\begin{array}{l}\text { status bars/ } \\
\text { progress bars }\end{array}$ & 0.574 & -0.114 & 1.908 \\
\hline FAF5 & $\begin{array}{l}\text { avatars/ } \\
\text { virtual identity/ } \\
\text { profile levels }\end{array}$ & 0.879 & 0.443 & 2.133 \\
\hline FAF6 & leaderboards & 0.565 & -0.028 & 1.665 \\
\hline
\end{tabular}

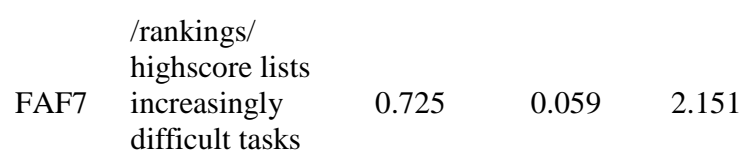

Interaction with social-related features

-The importance of interacting with

\begin{tabular}{lllll} 
ISF1 & competition & 0.835 & 0.369 & 1.963 \\
ISF2 & $\begin{array}{l}\text { team/ } \\
\text { cooperation } \\
\text { social } \\
\text { ISF3 }\end{array}$ & 0.810 & 0.130 & 2.457 \\
& $\begin{array}{l}\text { networking } \\
\text { features }\end{array}$ & 0.754 & 0.273 & 1.584 \\
-The frequency of interacting with & & \\
FSF1 & $\begin{array}{l}\text { competition } \\
\text { FSF2 }\end{array}$ & 0.655 & 0.034 & 1.739 \\
team/ & 0.782 & 0.249 & 1.878 \\
FSF3 & $\begin{array}{l}\text { cooperation } \\
\text { social } \\
\text { networking } \\
\text { features }\end{array}$ & 0.750 & 0.218 & 1.708 \\
\hline
\end{tabular}

3.3.2. Reflective measurement model. We assessed the validity and reliability of reflective measurement model. To check the properties of the measurement scales, we conducted confirmatory factor analysis (CFA) to assess reliability, convergent validity, and discriminant validity of the reflective constructs. We assessed convergent validity with three metrics: average variance extracted (AVE) and composite reliability (CR) and Cronbach's Alpha. Firstly, we investigated the loadings of the items and found the loading of item SBE 4 (I feel good about sharing my experiences with the products of the brand with others) was 0.319, which is lower than 0.6. By removing item SBE4, all Cronbach's a of variables are higher than recommended value 0.7 [33] and the AVE of emotional aspect of brand engagement (0.678), cognitive aspect (0.639) and social aspect $(0.630)$ and brand equity (0.543) were higher than 0.5 [13]. As for the construct reliability (CR), all values were between 0.876 and 0.913 , higher than 0.7 [13]. See Table 3 for more details.

As per discriminant validity, no inter-correlation of constructs exceeds the square root of the AVE of either of those compared constructs (see Table 4). The square root of the AVE of the three dimensions of brand engagement and brand equity is $0.824,0.799,0.794$ and 0.737 . We can conclude that the discriminant validity is met. 
Table 3. Reflective measurement

\begin{tabular}{|c|c|c|}
\hline \multicolumn{2}{|c|}{ Construct } & Loading \\
\hline \multicolumn{3}{|c|}{ Brand engagement } \\
\hline \multicolumn{3}{|c|}{ Emotional dimension } \\
\hline EBE1 & I feel excited about this brand & 0.817 \\
\hline EBE2 & I am heavily into this brand & 0.874 \\
\hline EBE3 & I am passionate about this brand & 0.741 \\
\hline EBE4 & I am enthusiastic about this brand & 0.797 \\
\hline EBE5 & I love this brand & 0.881 \\
\hline \multicolumn{3}{|c|}{ Cognitive dimension $\quad \mathrm{a}=0.812 \mathrm{CR}=0.876 \mathrm{AVE}=0.639$} \\
\hline CBE1 & I like to learn more about this brand & 0.763 \\
\hline CBE2 & $\begin{array}{l}\text { I pay a lot of attention to anything } \\
\text { about this brand }\end{array}$ & 0.812 \\
\hline CBE3 & $\begin{array}{l}\text { Anything related to this band grabs } \\
\text { my attention }\end{array}$ & 0.825 \\
\hline CBE4 & I think about the brand a lot & 0.796 \\
\hline \multicolumn{3}{|c|}{ Social dimension } \\
\hline SBE1 & $\begin{array}{l}\text { I love talking and using products of } \\
\text { the brand with my friends }\end{array}$ & 0.812 \\
\hline SBE2 & $\begin{array}{l}\text { I enjoy talking and using products of } \\
\text { the brand more when I am with } \\
\text { others }\end{array}$ & 0.758 \\
\hline SBE3 & $\begin{array}{l}\text { Talking and using products of the } \\
\text { brand are more fun when other } \\
\text { people around me do it too }\end{array}$ & 0.838 \\
\hline SBE4 & $\begin{array}{l}\text { I feel good about sharing my } \\
\text { experiences with the products of the } \\
\text { brand with others }\end{array}$ & omitted \\
\hline SBE5 & $\begin{array}{l}\text { I feel fellowship with other people } \\
\text { who use the products of the brand }\end{array}$ & 0.786 \\
\hline SBE6 & $\begin{array}{l}\text { I like recommending the products of } \\
\text { the brand to others }\end{array}$ & 0.773 \\
\hline \multicolumn{3}{|c|}{ Brand equity } \\
\hline \multicolumn{3}{|c|}{ Brand loyalty } \\
\hline BL1 & $\begin{array}{l}\text { I will not buy other brands if } \mathrm{X} \text { is } \\
\text { available at the store. }\end{array}$ & 0.700 \\
\hline BL2 & I am committed to this brand & 0.743 \\
\hline BL3 & $\begin{array}{l}\text { I will likely buy this brand the next } \\
\text { time I buy [product name, Huawei } \\
\text { or Xiaomi] }\end{array}$ & 0.747 \\
\hline BL4 & $\begin{array}{l}1 \text { would be willing to pay a higher } \\
\text { price for this brand over other } \\
\text { brands (assuming the products were } \\
\text { otherwise similar in features). }\end{array}$ & 0.719 \\
\hline \multicolumn{3}{|c|}{ Brand awareness } \\
\hline BA1 & I am very familiar with this brand & 0.738 \\
\hline BA2 & $\begin{array}{l}\text { I can recognize the brand among } \\
\text { other competing brands }\end{array}$ & 0.748 \\
\hline BA3 & $\begin{array}{l}\text { Some characteristics of the brand } \\
\text { come to my mind quickly if I think } \\
\text { about the brand. }\end{array}$ & 0.743 \\
\hline BA4 & $\begin{array}{l}\text { I can quickly recall the symbol or } \\
\text { logo of this brand }\end{array}$ & 0.738 \\
\hline BA5 & $\begin{array}{l}\text { It is not very difficult for me to } \\
\text { imagine this brand }\end{array}$ & 0.751 \\
\hline
\end{tabular}

Table 4. Discriminant Validity

\begin{tabular}{|c|c|c|c|c|c|c|c|}
\hline & IGF & AGF & SGF & EBE & $\mathrm{CBE}$ & SBE & $\mathrm{BE}$ \\
\hline IGF & N/A & & & & & & \\
\hline AGF & 0.282 & N/A & & & & & \\
\hline SGF & 0.258 & 0.248 & N/A & & & & \\
\hline EBE & 0.150 & 0.238 & 0.239 & 0.824 & & & \\
\hline $\mathrm{CBE}$ & 0.171 & 0.270 & 0.261 & 0.498 & 0.799 & & \\
\hline SBE & 0.193 & 0.275 & 0.287 & 0.511 & 0.572 & 0.794 & \\
\hline $\mathrm{BE}$ & 0.149 & 0.144 & 0.165 & 0.380 & 0.355 & 0.337 & 0.737 \\
\hline
\end{tabular}
$\mathrm{AGF}=$ achievement-related gamification features; $\mathrm{SGF}=$ social-related gamification features; $\mathrm{EBE}=\mathrm{emotional}$ brand engagement; $\mathrm{CBE}=$ cognitive brand engagement; $\mathrm{SBE}=$ social brand engagement; $\mathrm{BE}=$ brand equity. Naturally, for formative construct (IGF, AGF, SGF) AVE is not calculated.

\subsection{Results (structural model)}

The model explained $9.4 \%\left(\mathrm{R}^{2}=0.094\right)$ of the variance of emotional brand engagement, $11.7 \%\left(\mathrm{R}^{2}=\right.$ 0.117 ) of the variance of cognitive brand engagement, $13.2 \%\left(R^{2}=0.132\right)$ of the variance of social brand engagement and $19 \%\left(R^{2}=0.190\right)$ of the variance of the brand equity (Figure 1). The variance explained of the dependent variables is relatively low, indicating gamification features only can explain a small portion of brand engagement in brand communities. Surprisingly, brand engagement also explained a small part of the variability of brand equity.

Table 5. Structural equation model results

\begin{tabular}{llll}
\hline Path Coefficients & B & T & P \\
\hline IGF $\rightarrow$ EBE & 0.053 & 1.561 & 0.119 \\
IGF $\rightarrow$ CBE & 0.063 & 1.826 & 0.068 \\
$\mathrm{IGF} \rightarrow \mathrm{SBE}$ & $0.082 *$ & 2.371 & 0.018 \\
$\mathrm{AGF} \rightarrow \mathrm{EBE}$ & $0.178 * * *$ & 4.74 & 0.000 \\
$\mathrm{AGF} \rightarrow \mathrm{CBE}$ & $0.204 * * *$ & 5.789 & 0.000 \\
$\mathrm{AGF} \rightarrow \mathrm{SBE}$ & $0.198 * * *$ & 5.814 & 0.000 \\
$\mathrm{SGF} \rightarrow \mathrm{EBE}$ & $0.181 * * *$ & 5.208 & 0.000 \\
$\mathrm{SGF} \rightarrow \mathrm{CBE}$ & $0.194 * * *$ & 5.727 & 0.000 \\
$\mathrm{SGF} \rightarrow \mathrm{SBE}$ & $0.217 * * *$ & 6.265 & 0.000 \\
$\mathrm{EBE} \rightarrow \mathrm{BE}$ & $0.234 * * *$ & 6.547 & 0.000 \\
$\mathrm{CBE} \rightarrow \mathrm{BE}$ & $0.169 * * *$ & 4.319 & 0.000 \\
$\mathrm{SBE} \rightarrow \mathrm{BE}$ & $0.121 * *$ & 2.976 & 0.003 \\
\hline
\end{tabular}




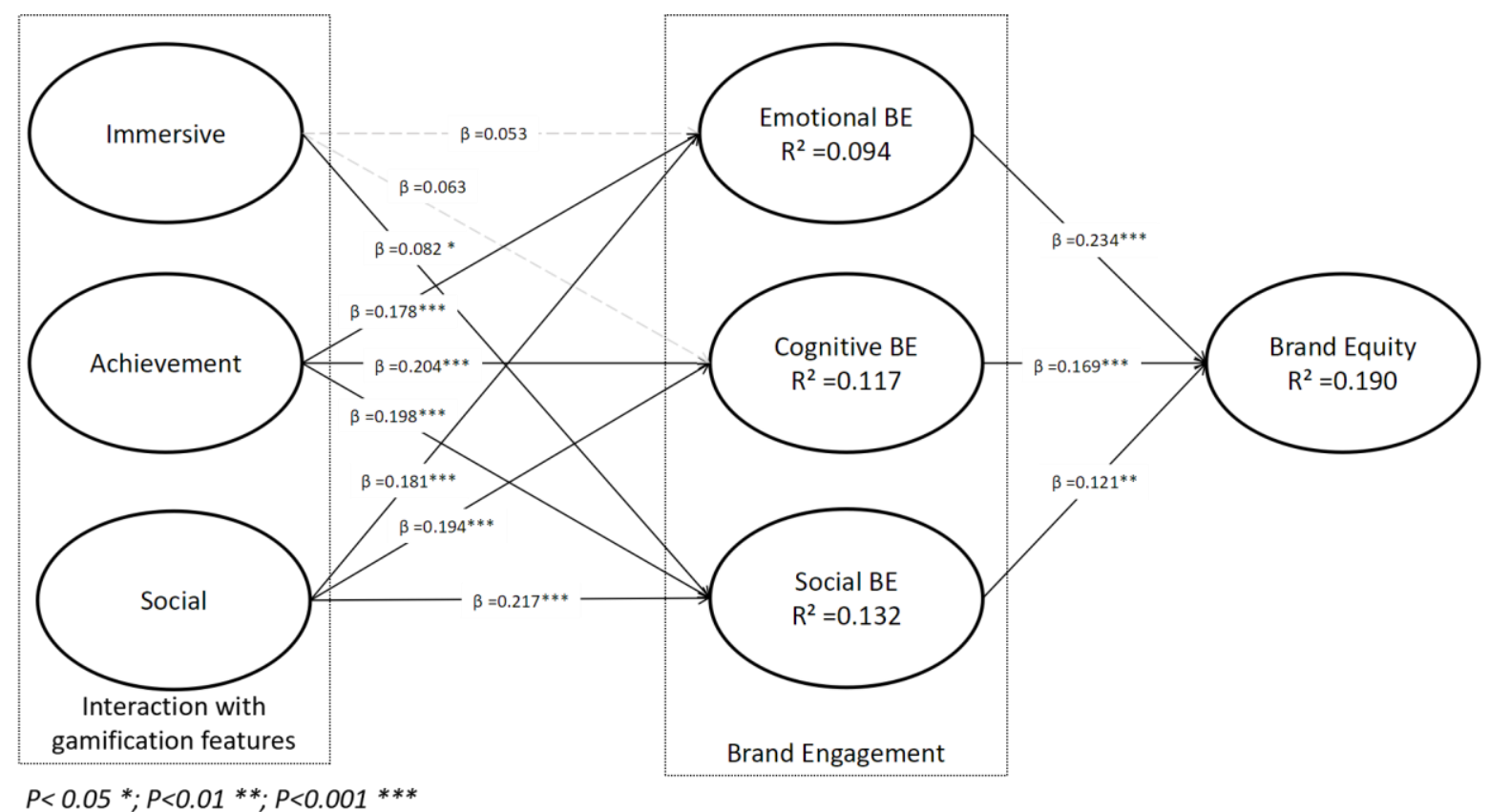

Figure 1. Results of structural equation model

As per the relationship between interaction with immersive-related features and emotional dimension of brand engagement, the results show that interaction with immersive-related features was not significantly associated with neither with emotional $(\beta=0.053$, $\mathrm{p}=0.119)$ or cognitive brand engagement $(\beta=0.063$, $\mathrm{p}=0.068$ ), but was positively associated with social brand engagement $(\beta=0.082, p=0.018)$. Thus, H1 cannot be supported according to the result. As per the relationship between interaction with achievementrelated features and brand engagement, interaction with achievement-related features was positively associated with cognitive brand engagement $(\beta=0.204, p<0.001)$. Moreover, interaction with achievement-related features was positively associated with the emotional brand engagement $(\beta=0.178, p<0.001)$ and social brand engagement $(\beta=0.198, \quad p<0.001)$. Obviously, the interaction with achievement-related gamification features was more strongly associated with cognitive brand engagement than with other dimensions of brand engagement. Therefore, the above results support $\mathrm{H} 2$. Similarly, interaction with social-related features was positively associated with all dimensions of brand engagement: emotional $(\beta=0.181, p<0.001)$, cognitive $(\beta=0.194, \quad p<0.001)$ and social brand engagement $(\beta=0.217, p<0.001)$. H3 was also supported. What's more, the three dimensions of brand engagement were significant positive associated to brand equity (for emotional brand engagement, $\beta=0.234, \quad p<0.001$; cognitive brand engagement, $\beta=0.169$, $p<0.001$; social brand engagement, $\beta=0.121, \mathrm{p}<0.001)$. Therefore, the results support H4. For the full result, please refer to Table 5.

\section{Discussion}

Gamification has been increasingly used as an essential part of today's services, software and systems to engage and motivate users as well as to spark further behaviour. So too has marketing domain adopted gamification as a way to increase the engagement with brand and further strengthen brand equity. However, beyond optimistic expectations, currently there has been a dearth of empirical evidence on whether gamification will be able to engage consumers. Therefore, in this study we investigated the relationship between the consumers' $(\mathrm{N}=824)$ interactions with gamification features (thirteen features divided across immersion, achievement and social-related feature constructs) and brand engagement (emotional, cognitive and social engagement) as well as further brand equity in Xiaomi and Huawei online gamified communities that represents two large technology product-related online brand communities in China through a survey-based study.

The results showed that achievement and socialrelated features were positively associated with emotional, cognitive and social brand engagement (H2 
and $\mathrm{H} 3$ not rejected). Immersive-related features were only positively related to social brand engagement (H1 predicting that interaction with immersive features would be associated with emotional and cognitive brand engagement was rejected). Furthermore, all dimensions of brand engagement were further positively associated with brand equity ( $\mathrm{H} 4$ not rejected). Overall, the results imply that there is positive chain of associations between gamification, brand engagement and brand equity. Gamification appears to be an effective tool for brand management.

The results that were contrary to the hypotheses afford further discussion points. The main deviation from the set hypotheses was that immersive features were not positively associated with emotional brand engagement. We can speculate that this may be because some of the immersion-related features such as avatars/virtual identity/profile and personalization features have a more of a social function as they afford displaying information about oneself to other and which can facilitate consumers to exchange information about the brand rather than so spur them to explore and immerse themselves into the brand by themselves. Moreover, interacting with immersive features was also more weakly associated with cognitive and social engagement compared to interacting with achievement and social features.

Another interesting aspect of the results was that interaction with both the achievement and social features were positively associated with all of the dimensions of brand engagement. It appears that they are able to afford a wide spectrum of (brand) engagement, and therefore, the results would imply that employing them on community websites seems like a fruitful approach. For example, pertaining to the achievement features, being high on the highscore list can at the same time afford a multifaceted experience of cognitive processes of figuring out how to win, emotional experience from the result as well as a social experience stemming from the resulting social prestige.

One of the strengths of the current study was that it measured the interaction of customers with thirteen gamification features but at the same time managed to group them into more generalizable larger entities. While such modelling strategy is able to investigate the phenomenon on a more latent and broader manner, a future research avenue would be to investigate the effects of every single gamification element individually. This may help bring more granularity to similar studies, however, at the same time a larger theoretical picture might start to fade. Moreover, the gamification features might be differently implemented across different services, and therefore, a research strategy focusing on testing each mechanic individually may end up losing external validity.
As is commonplace with survey-based studies, the data consists of self-reported measures. The data was collected in Chinese technology brand communities, and therefore, it is possible that results may differ between cultures and types of brands. To increase the generalizability of the findings, future researches can select different gamified services as the research contexts or conduct intercultural studies by examining the cross-cultural difference in consumer psychology and behaviour. Also, the longitudinal study can be considered to examine the long-term effect of gamification on brand management. Moreover, future studies could investigate possible moderating effects between gamification and brand engagement. For example, the interaction with gamification may translate differently to brand engagement depending on what kind of gaming history the consumers have, what kinds of players they are or depending on their demographic factors.

\section{References}

[1] D. A. Aaker, Managing brand equity: Capitalizing on the value of a brand name, New York, Free Press, 1991.

[2] J. C. Anderson, and D.W. Gerbing, "Structural equation modeling in practice: A review and recommended two-step approach", Psychological bulletin, 103(3), 1988, pp. 411-423.

[3] R. P. Bagozzi, "Structural equation models in marketing research: Basic principles", Principles of marketing research, Blackwell Publishing, Oxford, 1994, pp. 317-385.

[4] A. Berger, T. Schlager, D. E. Sprott, and H. Andreas, "Gamified interactions: whether, when, and how games facilitate self-brand connections", Journal of the Academy of Marketing Science, 81(2), 2017, pp. 1-22.

[5] R. J. Brodie, L. D. Hollebeek, B. JuriĆ, and A. Ilić, "Customer engagement: Conceptual domain, fundamental propositions, and implications for research", Journal of service research, 14(3), 2011, pp. 252-271.

[6] R. J. Brodie, A. Ilic, B. Juric B, and L. Hollebeek, "Consumer engagement in a virtual brand community: An exploratory analysis", Journal of Business Research, 66(1), 2013, pp. 105-114.

[7] R. T. Cenfetelli, and G. Bassellier, "Interpretation of formative measurement in information systems research”, MIS quarterly, 33(4), 2009, pp. 689-707.

[8] A. Chaudhuri, and M. B. Holbrook, "The chain of effects from brand trust and brand affect to brand performance: the role of brand loyalty", Journal of marketing, 65(2), 2001, pp. 81-93.

[9] W. W. Chin, B. L. Marcolin, and P. R. Newsted, "A partial least squares latent variable modeling approach for measuring interaction effects: Results from a Monte Carlo simulation study and an electronic-mail emotion/adoption study", Information systems research, 14(2), 2003, pp. 189-217. 
[10] T. Coltman, T. M. Devinney, D. F. Midgley, and S. Venaik., "Formative versus reflective measurement models: Two applications of formative measurement", Journal of Business Research, 61(12), 2008, pp. 12501262.

[11] A. Diamantopoulos, and H. M. Winklhofer, "Index construction with formative indicators: An alternative to scale development", Journal of marketing research, 38(2), 2001, pp. 269-277.

[12] A. Diamantopoulos, and J. A. Siguaw, "Formative versus reflective indicators in organizational measure development: A comparison and empirical illustration", British Journal of Management, 17(4), 2006, pp. 263282.

[13] C. Fornell, and D. F. Larcker, "Evaluating structural equation models with unobservable variables and measurement error", Journal of marketing research, 18(1), 1981, pp. 39-50.

[14] R. C. Gambetti, G. Graffigna, and S. Biraghi, "The grounded theory approach to consumer-brand engagement", International Journal of Market Research, 54(5), 2012, pp. 659-687.

[15] R. Gatautis, J. Banyte, Z. Piligrimiene, et al., "The Impact of Gamification on Consumer Brand Engagement", Transformation in Business \& Economics, 15(1), 2016, pp. 173-191.

[16] J. Hamari, "Transforming Homo Economicus into Homo Ludens: A field experiment on gamification in a utilitarian peer-to-peer trading service", Electronic Commerce Research and Applications, 12(4), 2013, pp. 236-245.

[17] J. Hamari, K. Huotari, and J. Tolvanen, "Gamification and economics", The Gameful World: Approaches, Issues, Applications, Cambridge, MA: MIT Press, 2015, pp. 139-161.

[18] J. Hamari, and J. Koivisto "Why do people use gamification services? International Journal of Information Management, 35(4), 2015, pp. 419-431.

[19] J. Hamari, and J. Tuunanen, "Player types: A metasynthesis", Transactions of the Digital Games Research Association, 1(2), 2014, pp. 29-53.

[20] J. F. Hair, C. M. Ringle, and M. Sarstedt, "PLS-SEM: Indeed a silver bullet", Journal of Marketing theory and Practice, 19(2), 2011, pp. 139-152.

[21] T. Harwood, and T. Garry, "An investigation into gamification as a customer engagement experience environment", Journal of Services Marketing, 29(6/7), 2015, pp. 533-546.

[22] S. Hoeffler, and K. L. Keller, "Building brand equity through corporate societal marketing", Journal of Public Policy \& Marketing, 21(1), 2002, pp. 78-89.

[23] C. F. Hofacker, K. De Ruyter, N. H. Lurie, et al., "Gamification and mobile marketing effectiveness", Journal of Interactive Marketing, 34(5), 2016, pp. 2536.

[24] L. Hollebeek, "Exploring customer brand engagement: definition and themes", Journal of strategic Marketing, 19(7), 2011, pp. 555-573.

[25] L. D. Hollebeek, M. S. Glynn, and R. J. Brodie, "Consumer brand engagement in social media: Conceptualization, scale development and validation",
Journal of interactive marketing, 28(2), 2014, pp. 149165.

[26] C. L. Hsu, and M. C. Chen, "How does gamification improve user experience? An empirical investigation on the antecedences and consequences of user experience and its mediating role", Technological Forecasting and Social Change, 132, 2018, pp. 118-129.

[27] K. Huotari, and J. Hamari, "A definition for gamification: anchoring gamification in the service marketing literature", Electronic Markets, 27(1), 2017, pp. 21-31.

[28] K. Hutter, J. Hautz, S. Dennhardt, et al., "The impact of user interactions in social media on brand awareness and purchase intention: the case of MINI on Facebook", Journal of Product \& Brand Management, 22(5/6), 2013, pp. 342-351.

[29] C. B. Jarvis, S. B. MacKenzie, and P. M. Podsakoff, “A critical review of construct indicators and measurement model misspecification in marketing and consumer research", Journal of consumer research, 30(2), 2003, pp. $199-218$.

[30] J. M. Jung, K. S. Min, and J. J. Kellaris, "The games people play: How the entertainment value of online ads helps or harms persuasion", Psychology \& Marketing, 28(7), 2011, pp. 661-681.

[31] M. Kang, D. H. Shin, and T. Gong, "The role of personalization, engagement, and trust in online communities", Information Technology \& People, 29(3), 2016, pp. 580-596.

[32] K. L. Keller, "Conceptualizing, measuring, and managing customer-based brand equity", Journal of Marketing, 57(1), 1993, pp. 1-22.

[33] R. B. Kline, "Principles, and Practice of Structural Equation Modeling", New York: Guilford Press, 1998.

[34] A. J. Kim, and E. Ko, "Do social media marketing activities enhance customer equity? An empirical study of luxury fashion brand", Journal of Business Research, 65(10), 2012, pp. 1480-1486.

[35] J. E. Kim, S. Lloyd, and M. C. Cervellon, "Narrativetransportation storylines in luxury brand advertising: Motivating consumer engagement", Journal of Business Research, 69(1), 2016, pp. 304-313.

[36] J. Koivisto, and J. Hamari, "The Rise of Motivational InformationSystems: A Review of Gamification Research", Working paper, 2017.

[37] W. Lassar, B. Mittal, and A. Sharma, "Measuring customer-based brand equity", Journal of consumer marketing, 12(4), 1995, pp. 11-19.

[38] M. Lee, and R. J. Faber, "Effects of product placement in on-line games on brand memory: A perspective of the limited-capacity model of attention", Journal of advertising, 36(4), 2007, pp. 75-90.

[39] P. B. Lowry, and J. Gaskin, "Partial least squares (PLS) structural equation modeling (SEM) for building and testing behavioral causal theory: When to choose it and how to use it", IEEE transactions on professional communication, 57(2), 2014, pp. 123-146.

[40] A. Majchrzak, C. Wagner, and D. Yates, "The impact of shaping on knowledge reuse for organizational improvement with wikis", MIS Quarterly, 37(2), 2013, pp. 455-469. 
[41] H. Nobre, and A. Ferreira., "Gamification as a platform for brand co-creation experiences", Journal of Brand Management, 24(4), 2017, pp. 349-361.

[42] W. Peng, J. H. Lin, K. A. Pfeiffer, and B. Winn, "Need satisfaction supportive game features as motivational determinants: An experimental study of a selfdetermination theory guided exergame", Media Psychology, 15(2), 2012, pp. 175-196.

[43] K. Robson, K. Plangger, J. H. Kietzmann, et al., "Game on: Engaging customers and employees through gamification”, Business Horizons, 59(1), 2016, pp. 2936.

[44] J. R. Rossiter, "The C-OAR-SE procedure for scale development in marketing", International journal of research in marketing, 19(4), 2002, pp. 305-335.

[45] M. Sigala, "The application and impact of gamification funware on trip planning and experiences: The case of TripAdvisor's funware", Electronic Markets, 25(3), 2015, pp. 189-209.

[46] C. J. Simon, and M. W. Sullivan, "The measurement and determinants of brand equity: A financial approach", Marketing science, 12(1), 1993, pp. 28-52.

[47] J. G. Snodgrass, H. J. F. Dengah, M. G. Lacy, and J. Fagan, "A formal anthropological view of motivation models of problematic MMO play: Achievement, social, and immersion factors in the context of culture", Transcultural psychiatry, 50(2), 2013, pp. 235-262.

[48] K. K. F. So, C. King, and B. Sparks, "Customer engagement with tourism brands: Scale development and validation", Journal of Hospitality \& Tourism Research, 38(3), 2014, pp. 304-329.

[49] D. Sprott, S. Czellar, and E. Spangenberg, "The importance of a general measure of brand engagement on market behavior: Development and validation of a scale", Journal of Marketing Research, 46(1), 2009, pp. 92-104.

[50] R. Terlutter, and M. L. Capella, "The gamification of advertising: analysis and research directions of in-game advertising, advergames, and advertising in social network games", Journal of Advertising, 42(2-3), 2013, pp. 95-112.

[51] S. D. Vivek, "A scale of consumer engagement", Tuscaloosa: The University of Alabama, 2009.
[52] S. D. Vivek, S. E. Beatty, V. Dalela, et al., "A generalized multidimensional scale for measuring customer engagement", Journal of Marketing Theory and Practice, 22(4), 2014, pp. 401-420.

[53] J. H. Washburn, and R. E. Plank, "Measuring brand equity: An evaluation of a consumer-based brand equity scale", Journal of Marketing Theory and Practice, 10(1), 2002, pp. 46-62.

[54] J. Wirtz, A, Den Ambtman, J. Bloemer, et al., "Managing brands and customer engagement in online brand communities", Journal of Service Management, 24(3), 2013, pp. 223-244.

[55] Y. Yang, Y. Asaad, and Y. Dwivedi, "Examining the impact of gamification on intention of engagement and brand attitude in the marketing context", Computers in Human Behavior, 73, 2017, pp. 459-469.

[56] M. Yang, D. R. Roskos-Ewoldsen, L. Dinu, et al., "The effectiveness of 'in-game' advertising: Comparing college students' explicit and implicit memory for brand names", Journal of Advertising, 35(4), 2006, pp. 143-152.

[57] N. Yee, "The psychology of massively multi-user online role-playing games: Motivations, emotional investment, relationships and problematic usage", Avatars at work and play, Springer, Dordrecht, 2006, pp. 187-207.

[58] N. Yee, N. Ducheneaut, and L. Nelson, "Online gaming motivations scale: development and validation", Proceedings of the SIGCHI conference on human factors in computing systems. ACM, 2012, pp. 28032806.

[59] B. Yoo, and N. Donthu, "Developing and validating a multidimensional consumer-based brand equity scale", Journal of business research, 52(1), 2001, pp. 1-14.

[60] M. Zhang, L. Guo, M. Hu, and W. Liu, "Influence of customer engagement with company social networks on stickiness: Mediating effect of customer value creation", International Journal of Information Management, 37(3), 2017, pp. 229-240.

[61] G. Zichermann, and J. Linder. Game-based marketing: inspire customer loyalty through rewards, challenges, and contests. John Wiley \& Sons, 2010 